\title{
Political Culture and Tourism Development: A Case Study of Tamil Nadu State
}

\author{
S. Fazal Daoud Firdausi \\ Assistant Professor, Competitive Examinations Centre, Savitribai Phule Pune University, Pune, Maharashtra, India \\ E-Mail: firdausi1982@gmail.com
}

\begin{abstract}
Tourism development in any region is influenced by political culture and processes. It is inherently linked to the policies, agenda, decisions, outcomes and the type of government responsible for shaping policies related to tourism. The paper tries to find out the impact of political culture on tourism development. It also aims to assess the role of political culture in influencing tourist motivation through the data collected from urban tourist centres of the Southern Indian state of Tamil Nadu. Mixed method, consisting qualitative interpretation as well as descriptive and inferential statistics has been used to draw conclusions. It has come out from the study that the political culture of Tamil Nadu state may be characterized as a mix of subject and participant culture, where latter dominates the former. It can be concluded that the people of the state have always participated in political process through voting and changing the regime from time to time. The study also indicates that most of the people of the state are aware of their political obligations and actively participate in social campaigns and civic life. It can be concluded that the existing political culture in the state has compelled the political elite to think and work for the development of the state, including tourism development.

Keywords: Political Culture, Tourism Development, Tourist Motivation
\end{abstract}

\section{INTRODUCTION}

The relationship between tourism and politics is tenacious, where former is greatly influenced by the latter at both local and global scale. Tourism development and its implication are linked to political system and political processes. Tourism is tied to different political ideologies, cultures that produce prominent variance in policy making, administrative structures and tourism experiences at the destination. Tourism has a powerful mix of cultural, economic and political phenomena but the political dimensions were largely ignored by the scholars until the episode of $9 / 11$ that invented 'other' in the sphere of travel and tourism (Burns, 2004). According to Burns, now tourism has become 'too political' and important to be dismissed. Political environment not only influences tourism marketing but it also has huge positive or negative impact on tourist motivations. The motivation to travel mostly depends on the ability of the destination to satisfy the experience of a tourist. The motivation to travel declines if the tourist perceives that the place is not worth its payment or the competitor is offering better quality service (Burns \& Novelli, 2007). The motivation of a tourist is also influenced by political environment, particularly political stability and instability. Tourism development in a region is also influenced by political culture and processes, inherently linked with the policy, agenda, decisions, outcomes and the type of government responsible for shaping policies related to tourism and to set the growth trajectory of tourism in right direction. Any change in political culture affects the prominence given to tourism planning, resource allocation and decision making (Henderson, 2002, p. 21)

\section{RESEARCH METHODOLOGY}

There were two objectives of the study, first to study the relationship between political culture, tourist motivation and tourism development. Second was to identify the linkages between political culture, political environment and growth of tourism. To achieve the objectives, field study was conducted at the micro-level in the urban tourist centers of Tamil Nadu. The respondents were based in major urban tourist centers of the region such as Chennai, Aurovile, Cuddalore, Chidambaram, Madurai, Thanjavur, Rameswaram and Kanyakumari of the state of Tamil Nadu.

Total sixty (60) local residents (respondents) from above mentioned urban tourist centers of Tamil Nadu have been surveyed through structured questionnaire. It included questions related to their orientation and attitude towards the political objects and political system existing in the state of Tamil Nadu. The impact of political culture and political environment on tourist motivation and growth of tourism has been outlined using primary and secondary information. Finally, statistical technique has been applied to ascertain the relationship between infrastructure development and tourism development in the region.

\section{POLITICAL CULTURE AND TOURISM IN TAMIL NADU}

\section{A. Cognitive Orientation: Knowledge, Belief and Awareness}

According to Almond and Verba (1963) the study of cognitive patterns and its analysis is important to understand the political culture of any region. Cognitive patterns explain how knowledgeable the general communities are about different features and the aspects of a political system. It helps us to understand political objects, its structures, processes, and roles in nations, social and economic life. It is also useful to present a comparative analysis of different groups. The cognitive orientation regarding political objects 
have been assessed by taking responses regarding belief in the notion of citizenship, awareness about political obligations, expression of political opinions, discussion on politics and association with political parties. According to Webster's dictionary, Citizenship is the relationship between an individual and a state in which individual owes allegiance to the state and in turn entitled to its protection. The respondents were asked whether they believe in this notion that they are citizens of India. About 95 percent of them considered themselves as proud citizens of India, while 5 percent replied in negative. It reflects that the divisive and fissiparous tendencies are diminishing that were once strong in 1950s and 1960s. Political obligations are defined as having moral duty to obey the laws of the country and state. In cases where an act or forbearance that is required by law is morally obligatory on independent grounds, political obligation simply gives a citizen an additional reason for acting accordingly.

Around 73 percent of the respondents expressed that they are aware of their moral duty of respecting state's and nation's law, whereas some 27 percent were not aware of their political obligations. This shows a relatively high level of political awareness among people about their moral duties as citizens. Expression of political and civic engagement is fundamental to a democracy. About 90 percent of the respondents were aware of the mediums of political expression, while 9 percent of respondents stated that they do not have any idea about the medium of political expression. Among those who were aware, 50 percent preferred voting as the major source of expressing their political opinions. Some 26 percent considered public meetings as the best possible way to express political opinions. Around 15 percent gave importance to media, which included print (newspapers/magazines/journals), electronic (television and radio) and social media (Facebook, twitter, blogs etc.).

The people who considered media as a tool for expressing their political opinions is of mixed age group but having dominance of people with 20-35 years of age, majority of them had higher educational qualifications. Around 92 percent of respondents stated that they had regular discussions on international, national and state political issues with family and friends, while 8 per cent did not indulge in any formal or informal political discussions. It shows that majority of the people were aware of latest political developments, which is good for the civic health of the region. The orientation of people regarding political efficiency can be best understood by knowing the belief of people about the government's response to one's opinion. It can also be analyzed on the basis of people's belief on civil society activism and the belief related to political change. In the present study, around 52 percent of respondents accepted that the state and central government have been responsive to their opinions. At the same time 48 percent of respondents stated that government is least responsive to people's opinion. Around 70 percent of the respondents believed that civil society activism can alter political decisions. Huge number of respondents (97 percent) believed that possibility of social and political change is good for the society. It is important as it infuses the society and system with newer ideas and breaks the monotony in policies adopted by the state. It positively alters the lives of the people in a society, therefore essential for the development of civic culture.

\section{B. Affective Orientation}

It includes feelings and opinions about 'system affect' and 'output affect'. System affect contain general attitudes towards the system, i.e. the nation and its virtues, accomplishment and the like, the output affect means the attitude people have towards executive or administrative agencies. On the contrary 'input affects' implies feelings people have about the agencies and processes that are involved in the election of public officials and enactment of general policies (Goswami, 2002, p.134). To find about the affective orientation of the people of the region, questions related to their feelings about national symbols, regime orientations and political identification have been asked. When asked about their respect for national symbols such as National Flag, Anthem, Song, Bird and Flower, about 95 percent of the respondents replied in positive. Similarly, 92 percent of respondents reported that they respect government institutions. Those who did not show respect were only 8 percent of the total. In general, majority had respect for the national symbols and national institutions. When asked about the political units (nation, state, town and village) or geographic areas to which one feels attachment and sense of belongingness, the response was very interesting. About 48 percent of respondents showed their utmost loyalty towards the nation. Interestingly around 40 percent of respondents considered their highest loyalty for the state. This implies that grip of Tamil sub-culture over Indian political culture has loosened in the recent times. Some 8 percent of respondents stated highest loyalty for their town, whereas only 3 percent considered their highest loyalty for the village.

Dissenting views within the political parties and groups over certain policies is very important for democratic functioning of the political system. Dissent within the party may alter the political decisions and directions which may positively affect the lives of the people. When asked about showing dissent, especially when favored political party takes deviation with regard to basic principles. About 43 percent replied positively, while 57 percent respondents reported that they do not show any dissent when their political party takes a stand against its established principles or works against the wishes of individual members. High number of replies in negative shows that, political parties present in the state lack inner party democracy. It is evident as most of these parties were led by single leader and their family members. People consider them charismatic and idolize them, and some of them have been elevated to the ranks of god. However, substantial number of respondents 
also feels that dissenting voices are essential for proper functioning of political system.

\section{Evaluative Orientation}

Evaluative orientation is about the judgment and opinions related to political objects that typically involve the combination of values, standards with information and feelings. To analyze the evaluative orientation questions related to ranking of government institutions, feelings about policies benefiting schedule caste/tribes/other backward caste (OBCs), ethnic, linguistic and religious minorities and level of cooperation among different people have been asked. The study shows that among the three government institutions (executive, legislative and judiciary), the legislative plays a significant role in parliamentary system of government. Under such a system the legislature is superior to executive. Making law is the main function of the legislature. Legislative was having lowest popularity among the respondents as only 8 percent people put it on first rank in terms of popularity. On the other hand the executive was moderately popular with 32 percent of respondents giving it first rank. Judiciary in India is having reputation of being independent and non-partisan. Judiciary has many times taken suo moto cognizance when the executive failed to perform their duties, or on the issues related to the interest of common people. The same popularity of judiciary is reflected in the results, as around 60 percent of respondents provided it first rank among the three institutions.

When comes to the level of cooperation in public sphere by the respondents with people from different caste, community and religion, around 43 percent of them replied that they are very cooperative in public sphere, which is essential for building the trust in political system. About 12 percent were reluctant to cooperate with 'others' in the public sphere, while 5 percent reported that they are not at all cooperative with people from different caste, community and religion in public sphere. Very interestingly those who were reluctant and not cooperative in public sphere belonged to diverse profession such as lawyer, student, pensioner, government employee, marketing executive, engineer and shopkeepers. The idea of social justice in India is providing reservation to the community, who were oppressed in historical times and currently in disadvantageous and underprivileged positions such as schedule caste, schedule tribes, other backward caste, ethnic and religious minorities. Albeit the idea of social justice in India is still debated, as scholars feel that wider measures like land reforms, income generation policies, redressal of inequality and securing well-being for the underprivileged are needed to promote social justice (Chandoke, 2004). People were asked about their views on state's idea of social justice and its continuation. A good number of respondents (60 per cent) agreed to Indian state's idea of social justice for SC/ST and OBCs, while 17 percent were negative about the idea. Some 23 percent preferred not to say anything on the issue. On the other hand only 43 percent of respondents agreed to the government's policy of providing reservation to religious minorities. More than quarter of the respondents did not like the idea of continuing reservation to religious minorities, whereas a substantial number (27 percent) preferred not to say anything on the issue. It is interesting to observe that while large population of the country and state have accepted reservations to SC/ST and OBCs as a part of their social and political reality. However, majority of them were still reluctant to provide similar privileges to religious minorities.

\section{Political Competence and Efficacy}

For the progression of the civic culture and strong political integration, formal and passive e.g. voting and informal e.g. forming political groups and talking about politics is essential. There must be a balance between directive and acquiescent attitudes. The study has tried to assess the passive attitudes through analysis of voting of the respondents. It also intends to bring out participant attitudes through evaluation of their active participation in social, political campaigns and use of their political resources. The study shows a tremendous formal and passive political participation by the respondents. The majority of them have participated in Assembly Elections that was held in 2016, brought AIADMK to power. About 85 percent of the respondents took part in the $16^{\text {th }}$ Lok Sabha elections held in 2014. Around 35 percent of them also voted in their village Panchayat polls. Those who voted in Panchayat elections were migrants from the villages to cities for employment purposes but they have not lost connection with their village. They have been frequently travelling to the village, either to meet their families or to take part in social events. Among the respondents, 55 percent have been voting in various elections from more than five years. Only 5 percent of them have been exercising their franchise from three years. A good number of them have been voting for two years. The remaining respondents were first time voters. The respondents have been asked about their frequency of use of political resources directly, i.e. meeting the political elite or the representatives of political parties, their Member of Parliament and Member of State Assembly for making demands and grievance redressal. Only 7 percent of them responded their frequency to be very high and 8 per cent stated to be high. A substantial number (33 percent) reported it to be medium, while more than 50 percent occasionally or rarely used their political resources. Similarly, around 52 percent of the respondents replied negative about their political activism, while 48 percent considered themselves politically active. Almost identical pattern was observed in their direct participation in political campaigns, as around 57 percent mentioned that they do not participate in any political campaign, while 43 percent at some point of time participated in some sort of political campaigns in association with particular political groups. Looking at the results and pattern one can infer that majority of respondents attitude towards passive participation is positive. However, when it comes to actively participate in political life, most of them are not 
fully inclined to take part in political activities. On the other hand 53 percent of them reported that they actively participate in social campaigns. Similarly, an outstanding (75 percent) number of respondents reported that they actively participated in civic life. This shows that although people are divided about actively participating in political life but many of them have a great zeal to contribute towards the betterment of the society.

It shows that the political culture of Tamil Nadu state may be characterized as a mix of subject and participant culture, where latter dominates the former. Idolizing of political elites by the people actually hinders pro-active participation of people in the politics of the state. On the other hand, it has given free hand to the ruling elite to take necessary initiatives and freedom to take decisions on tough policy issues. However, consociation among the political elite is extremely low within the assembly/parliament as well as outside. It is also manifested in regional media, controlled by opposing political elites of the state. Large group of population has always remained active in politics through taking part in political campaigns of their favored political parties. Many of them have also dissented when their respective parties diverted from core issues. They have always tried to make the elite sensitive to popular views and perceptions. The population of state has always taken part in politics through voting and changing the regime indulged in corruption and mass appropriation of wealth. Most of them are aware of their political obligations and actively participate in social campaigns and civic life. This culture has forced the political elite to think and work for the welfare of the people of the state. Due to such type of political orientations of people, parties had to set aside old rhetoric and collaborated with both regimes, the National Democratic Alliance (NDA) and United Progressive Alliance (UPA) at the centre. It helped the State to get funds for welfare schemes and infrastructure development projects. Tamil Nadu has become one of the most industrialized states in India. At present many heavy engineering and manufacturing based companies are located near Chennai, therefore it is nicknamed as 'Detroit of India' (Rao \& Reddy, 2009).

Tamil Nadu has not only performed in the field of industrialization but has outperformed many states in public welfare programmes. According to a report published in newspapers, Public Distribution System (PDS) has been working very successfully in the state of Tamil Nadu. It may be attributed to the political commitment or high level of awareness among the people. PDS has remained a big election issue for all the political parties in Tamil Nadu, whichever government came to power it has to ensure proper working of PDS. This is an important reason why illegal "diversion" of PDS grains (to the open market) appears to be very low in Tamil Nadu. Only 4 percent of the total, according to an estimate compared with 90 percent or so in Bihar (Alamu, 2011). Similarly, Tamil Nadu has done excellent in implementation of National Rural Health Mission (NRHM). Tamil Nadu has been described as a benchmark in the implementation of NRHM. The institutional deliveries were reported to be highest in Tamil Nadu (96.6 percent) family planning services (63.3 percent). As far as utilization of public versus private health facilities for chronic disease treatment is concerned, the majority of patients were utilizing public health facilities (94 percent) in Tamil Nadu (Dhar, 2013). Tamil Nadu is also performing fairly well in terms of social justice. No major incidence of caste and communal violence has been reported from the state, except of few skirmishes.

\section{E. Growth of Tourism in Tamil Nadu}

The existing political culture of Tamil Nadu has influenced tourism directly and indirectly. Industrial development, agricultural growth, welfare schemes for the population and better law and order system has not only enhanced the standard of life of the people but also indirectly affected the tourism through huge investments in tourism sector by individual and government that has influenced the motivation of tourist to visit the state. All the successive governments have given high priority to tourism development and it has remained high on agenda to upgrade tourism infrastructure (roads, railways and telecommunication) and superstructure (hotels, restaurants and tourist utility services). Several policies have been floated by the government to strengthen the tourism sector, using tourism as a tool for livelihood creation for the poorest of the poor. In the past, little official attention was given to tourism until 1958 when tourist offices were setup at Madurai and Ootacumund. The first state sponsored schemes were proposed as a part of Second Five Year Plan (1957-1962). There were small projects involving the construction of tourist bungalows at Nagercoil, Madurai, Courtallam and Tiruchirapalli. Seven additional schemes were initiated in the Third Five Year Plan (1962-1967). Six additional schemes were initiated in the Fourth Five Year Plan (1969-1974) with government of India providing Rs. $2,750,000(\$ 350,000)$ out of the total expenditure of Rs. $3,685,000$ (\$450,000) (Hyma and Wall, 1979).

Tamil Nadu State Tourism Development was set up in 1971, which use to oversee the administrative and promotional activities including hotel classification, publicity, and the approval of plans (Dhar, 2013). Tamil Nadu received 38100 tourists in the year 1971 that was 32.5 percent higher than the number of tourists it received in 1970. The tourism industry received a major boost after it was opened to private sector in 1990s, when India accepted free market economy. Post liberalization, private sector invested huge capital in tourism, new forms of tourism such as Theme Parks came into foray. Comprehensive steps were taken to improve tourism sector and attract international visitors in the year 2003. Tamil Nadu organized $64^{\text {th }}$ SKAL World Congress in Tamil Nadu in 2003.

It was the major turning point in the history of tourism in the state. Many agendas were adopted, including improving accessibility through upgrading the transport network and 
filling up micro-level infrastructure gaps in the major tourist destinations. At present, the transport system has been significantly improved. Tamil Nadu now has a wellestablished transportation system that connects all parts of the state. There are 24 national highways covering a total distance of $2002 \mathrm{Km}$. State is also a terminus for the Golden Quadrilateral Project. The state has a total road length of $167,000 \mathrm{Km}$. It is nearly 2.5 times higher than the density of all-India road networks. Tamil Nadu has a well-developed railway network as part of southern railway. Chennai has a well-established sub-urban railway network and has developed a Metro. Chennai has become a major International Airport that is connected with 19 countries with more than 329 direct flights every day (Rao \& Reddy, 2009). Chennai port is an artificial harbor situated on the Coromandel Coast and it is the second principal port in the country.

Tamil Nadu has witnessed a continuous and consistent rise in the number of tourist arrivals since 1993. The total number of tourists visiting Tamil Nadu was 14647 thousand in 1993. Afterwards there is an upward trend both in case of domestic and foreign tourists. The total number of tourist arrivals in 2003 was 27960 thousand. It witnessed sharp rise and reached 52400 thousand in the year 2006. In 2010 the total arrivals of tourists in the state crossed 10 crore mark.

The total number of arrived tourist in the state in 1993 was only 13 per cent of the tourist arrival in 2010. The whooping figure of total arrivals in the state in 2010 was 7 times of what it received in the year 1993. Conducive environment and better facilities have positively impacted the motivation of tourists as well as investors. It has now positioned itself as a not-to-be missed tourist destination of the world.

TABLE I TAMIL NADU URban ROAD LENGTH \& TOURIST ARRIVALS

\begin{tabular}{|l|c|c|}
\hline YEAR & $\begin{array}{c}\text { Total Urban Road } \\
\text { Length (in Km) }\end{array}$ & $\begin{array}{c}\text { Total Tourist } \\
\text { Arrivals }\end{array}$ \\
\hline 1997 & 14132 & 19564686 \\
\hline 1998 & 14536 & 21049593 \\
\hline 1999 & 14795 & 21859383 \\
\hline 2000 & 11882 & 23768047 \\
\hline 2001 & 12124 & 24585116 \\
\hline 2002 & 12300 & 25466395 \\
\hline 2003 & 13895 & 27960506 \\
\hline 2004 & 14821 & 31134844 \\
\hline 2005 & 16067 & 33518787 \\
\hline 2006 & 16602 & 40550382 \\
\hline 2007 & 17259 & 52400291 \\
\hline
\end{tabular}

Data Source: Indiastat.com \& Tourism Commissioner, Chennai, 2010

To examine the relationship between infrastructure development and growth of tourism in the State of Tamil Nadu a 2-tailed correlation exercise has been carried out using data on total urban road length (in $\mathrm{Km}$ ) and total tourist arrivals from 1997 to 2007. The calculated Pearson correlation score was 0.737 with the significance level of 0.010 (Table I) which is lower than 0.05 , hence it shows a positive correlation. It has been found that there is a positive correlation between indicators of infrastructure development and tourism growth in the state.
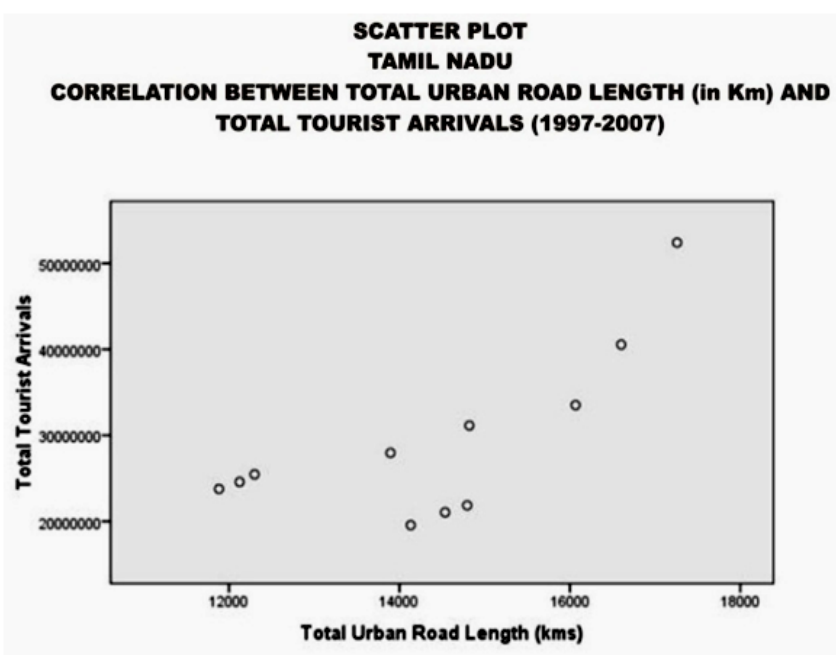

Fig. 1 Scatter Plot (Correlation between Total Urban Road Length \& Total Tourist Arrivals)

TABLE I CORRELATION - SigNIFICANCE LEVEL (TOTAL URBAN ROAD LENGTH \& TOTAL TOURIST ARRIVALS)

\begin{tabular}{|l|l|c|c|}
\hline & & $\begin{array}{c}\text { Total Urban } \\
\text { Road Length } \\
(\mathbf{k m})\end{array}$ & $\begin{array}{c}\text { Total } \\
\text { Tourist } \\
\text { Arrivals }\end{array}$ \\
\hline \multirow{3}{*}{$\begin{array}{l}\text { Total Urban } \\
\text { Road Length } \\
(\mathrm{km})\end{array}$} & $\begin{array}{l}\text { Pearson } \\
\text { Correlation }\end{array}$ & 1 & $.737^{* *}$ \\
\cline { 2 - 4 } & Sig. (2-tailed) & & .010 \\
\cline { 2 - 4 } & $\mathrm{N}$ & 11 & 11 \\
\hline \multirow{3}{*}{$\begin{array}{l}\text { Total Tourist } \\
\text { Arrivals }\end{array}$} & $\begin{array}{l}\text { Pearson } \\
\text { Correlation }\end{array}$ & $.737^{* *}$ & 1 \\
\cline { 2 - 4 } & Sig. (2-tailed) & .010 & \\
\cline { 2 - 4 } & $\mathrm{N}$ & 11 & 11 \\
\hline \multicolumn{2}{|l|}{$* *$ Correlation is significant at the 0.01 level (2-tailed). } \\
\hline
\end{tabular}

It reveals that favorable political environment has led to the development of good infrastructure facilities; as a consequence the State has also witnessed consistent increase in the tourist arrivals. It shows that the orientation of people towards politics and political system in the region has compelled the political elite to work and devise policies for the benefit of the people, including tourism.

Tourism development is still the prominent goal of the present government. Tamil Nadu government has come up with a vision Tamil Nadu 2023 document. The government plans to increase investments in various projects relating to tourism infrastructure to Rs. 10,000 Crores and expected foreign tourist flow would be 1.5 Crores by 2023 .

All the major national dailies carried out a full page advertisement of the highlights related to tourism in the 
Vision Document. It shows the value and importance given to the sector by the ruling elite that would definitely benefit the sector in future and motivates the tourists to visit the region and the state again and again.

\section{CONCLUSION}

It can be concluded that the process of political socialization and the political orientation of the people of the state has changed from time to time. In Tamil Nadu, the Dravidian parties have remained strong, active and popular before economic restructuring of 1990s. In the recent times, the views of these parties have softened. They have made alliances with national parties in Assembly as well as Lok Sabha polls. Even though, the ruling parties of the state are having huge political differences, despite of that they have managed to work for the development and welfare of the state.

It is evident from industrialization, transport, communication and tourism development. The Government of Tamil Nadu has been able to instill high level of confidence in the minds of guests (the tourists) regarding their safety and availability of world class infrastructure. The policies for tourism development have focused on the development of infrastructure and superstructure. Strong participation of people in civic activities and their allegiance with the political system has led to the creation of political and social environment that is beneficial for tourism in Tamil Nadu.

\section{REFERENCES}

[1] Henderson, J. C. (2002). Tourism and Politics in Korean Peninsula, The Journal of Tourism Studies, 13(2), 21.

[2] Goswami, R. D. (2002). Orientation Cognitive, Affective and Evaluative of IAS Officers in India, International Review of Sociology, 12(1), 134.

[3] Chandhoke, N. (2004, Aug 16). Reservations about reservation, The Hindu, Retrieved from: https://www.thehindu.com/2004/08/16/ storie/2004081 600881000.htm

[4] Rao, M. S \& Reddy, V.R. (2009). Encyclopedia of South India: Tamil Nadu, Mittal Publications, New Delhi

[5] Alamu, R. (2011, Sep 25) It just works in TN, The Hindu, Retrieved from: https://www.thehindu.com/features/magazine/it-just-works-intn/article 2475948.ece

[6] Dhar, A. (2013, Jan13) Tamil Nadu tops in NRHM Implementation, Retrieved from The Hindu, https://www.thehindu.com/news/nation nal/tn-tops-in-implementation-outcomes-of-nrhm/article4302309.ece

[7] Hyma, B. \& Wall, G. (1979).Tourism in a Developing Area: The Case of Tamil Nadu, India, Annals of Tourism Research, July/Sept, 345 .

[8] Almond, A. G \& Verba, S. (1963). The Civic Culture: Political Attitudes and Democracy in Five Nations, London: Sage Publications.

[9] Burns, P. M. \& Novelli, M. (2007). Tourism and Politics: Global Frameworks and Local Realities, Amsterdam: Elsevier. 